\title{
LAUGHTER IN THE FILM THE THIRD MAN
}

\author{
Daniel C. O’Connell and Sabine Kowal
}

\begin{abstract}
Two types of laughter were investigated in both the English- and the German-language versions of the film noir The third man (Korda, Selznik, \& Reed 1949, 1962): ha-ha laughter and laughter overlaid on spoken words. The present authors' transcripts constituted the database of the investigation. These were compared with other available versions: In English, the original novel (Greene 1950), the screenplay (Greene 1984), and a www.geocities.com transcript; in German, the novel in translation (Greene 1962) and a partial transcript (Timmermann \& Baker 2002). Very little laughter is noted in any of these other versions, and what does occur is innocuous (embarrassed, ironic, humorous, or pleasant) laughter. The authors' transcripts in both the English- and German-language versions, however, reveal abundant negative (cynical, hypocritical, or mendacious) laughter on the part of the criminal characters: The first (Baron Kurtz), the second (Mr. Popescu), and above all, the third man (Harry Lime). This laughter constitutes a notable change from both the medial and conceptual literacy of the novel and other written versions to the medial and conceptual orality of the film itself as a portrayal of spontaneous spoken dialogue. Laughter always reveals the personal perspective of the laugher and is used deliberately and skillfully as a rhetorical device. With the help of the villain's sardonic laughter, the third man's evil character is established in less than twelve minutes of dialogue. Such laughter is a far cry from the "instinctive, contagious, stereotyped, unconsciously controlled" ha-ha laughter described by Provine (2004: 215), from his "curious hybrid" (ibid.: 216) thereof (laughter overlaid on spoken words), and from the nonseriousness of laughter postulated by Chafe (2003a).
\end{abstract}

Keywords: Laughter, Film noir, The third man, Rhetoric, Spoken dialogue, Orality/literacy.

\section{Introduction}

There is no doubt that the category film noir fits the motion picture The third man (Korda, Selznik, \& Reed 1949) like a glove. From the very first moment, the black and white scenes of post WW-II Vienna suggest sinister and grim intrigue, mystery, and criminality. The definition of film noir is meticulously fulfilled: "A type of crime film featuring cynical malevolent characters in a sleazy setting and an ominous atmosphere that is conveyed by shadowy photography and foreboding background music" (Merriam-Webster's collegiate dictionary $11^{\text {th }}$ ed. 2003: 468).

A scenario such as the foregoing hardly suggests to the audience the salience of laughter. For example, the stereotypical reaction of questioned viewers of The third man is to simply negate that they found any laughter therein. People who think of The third man as one of their favorite films, or who have just viewed it, would not think of laughter as an important part of its narrative dynamic. In fact, if there is anything to be 
said in favor of a certain symmetrical relationship between the phenomena of laughing and crying (see, e.g., Plessner 1961: 229), then a dominance of crying, not of laughing, should be expected in this movie. There is nothing lighthearted about it.

Theoretical considerations lead to similar expectations. Chafe (2003a: 41; see also Chafe 2003b), in particular, has asserted that laughter is associated with "the feeling of nonseriousness" and that this feeling is a "pleasant" one. But nonseriousness and pleasantness are clearly absent as characteristics of The third man; grimness and unpleasantness are indeed characteristic: Murder, black-market dealings, betrayal, and stealth all come down on the dark side of human behavior. Graham Greene (1950: 14 f.) himself characterizes his story as "rather sad," "an ugly story if you leave out the girl: grim and sad and unrelieved if it were not for the absurd episode of the British Cultural Relations Society lecturer [Crabbin]." From these unpleasant details, Chafe could hardly predict laughter.

At the same time, it is well known that laughter serves many masters. It can be hilarious, amused, benevolent, and contagious, but also cynical, mean, inappropriate, arrogant, and disdainful. Provine $(2000,2004)$ and Glenn (2003) have reviewed the empirical literature on laughter from psycholinguistic and conversation analytic (CA) points of view, respectively, and have arrived at divergent conclusion regarding the nature and functions of laughter. The notion that it is simply "spontaneous and relatively uncensored," revealing "our true feelings" (Provine 2004: 216) seems quite oversimplified in view of Glenn's (2003: 170) assertion: "Laughter resists easy formulations." And so, we have taken a cue from Glenn (ibid.: 31) to search for techniques "to investigate the fine details of laughter in natural settings." Our own studies of Hillary Clinton's, Bill Clinton's, and their interviewers' laughter (O'Connell \& Kowal 2004: 476, 2005) have already indicated that laughter must always be considered "a nonverbal expression of personal perspective." It is certainly true that laughter begins during early human development as a stereotyped response (see the early work of Washburn 1929), but laughter later becomes overlaid by many verbal habits and is indeed sometimes expressed by means of words rather than simply as socalled ha-ha laughter. It is our assumption that, beyond the earliest stages of human development, laughter can serve as "a deliberate, sophisticated, and rhetorical device" (O’Connell \& Kowal 2005: 275).

With these reflections as background, we come to the hypothesis that, despite the gloomy earnestness and sinister ugliness portrayed in The third man, the actors may indeed use laughter in a sophisticated manner to reflect nonverbally a portion of their portrayal of the grim narrative dynamic of the film. The question becomes the more interesting insofar as the German synchronized version (Korda, Selznik, \& Reed 1962) of the motion picture is also available, along with a translation (Greene 1962) of the original novel into German. How the German synchronizers reflect the Englishlanguage actors' laughter can tell us even more about the artistic use of laughter in such subtle settings. The expectation that crying should be dominant over laughter in classical film noir can also be tested, even though there are only a few characters in the course of the entire film who would be at all likely to weep. 


\section{Rationale for the research}

The film production of The third man was anything but a simple scenario of Graham Greene's (1950: 7) novel, which he himself characterized as "never written to be read but only to be seen," and we would add: And to be heard. In consultation with Carol Reed, Greene wrote the screenplay "which Reed changed in the shooting and editing of the film" (Sinclair 1984: 6). A transcript of the English-language version of the film was also available to us from www.geocities.com but was found to include numerous errors, mostly of omission, that had to be corrected to obtain a definitive transcript for use in our analyses. A German-language transcript had to be prepared from scratch, although Timmerman and Baker (2002) provide at least a partial transcript - almost half the syllables (syl) of the German-language version of the film $(6,802 / 14,195 \mathrm{syl}=48 \%)$.

The transformation of Greene's novel into transcripts of film performances in both the English and the German languages is not just literary history; it is also an essential link in the rationale of our empirical investigation of The third Man. The relationship of the written to the spoken - of literacy to orality - has long been neglected in the modern sciences that have to do with language use. Linell (1982/2005) refers to this historic neglect as The written language bias in linguistics in the title of his book. This title implies that: "Scholars, as well as lay people, take written language, or rather certain forms of written language, as the norm for language, for its structure, use, and description" (Linell 1998: 28). But the written language bias does not describe specifically the presuppositions that went into the transformation from novel into film performance at the hands largely of Graham Greene and Carol Reed. As mentioned above, Greene (1950: 7) was convinced that "The third man was never written to be read but only to be seen." He was acutely aware of the fact that the well-formed sentences of that short volume would have to undergo "interminable transformations" (ibid.: 8) to become a film: "One cannot make the first act of creation in script form" (ibid.: 8), but neither can performance art stay with "the dull shorthand of a script" (ibid.: 8). In the screenplay of The third man (Greene 1984: 12), a specific convention is used to indicate further changes from the screenplay to the film performance: "Footnotes show any important additions made to the script by the completed film." Sinclair (1984: 6) reflects on this process: "Such are the changes and compromises that lie between a screenplay and a film."

In the following, we will argue that not even the footnotes in the screenplay (Greene 1984: 12) and not even the www.geocities.com English transcript and the German partial transcript (Timmermann \& Baker 2002) contain by a long shot all "the important additions made to the script by the completed film" (Greene 1984: 12). Both the screenplay and its page footnotes, as well as the published English and German transcripts, all retain a vestigial adherence to the written language bias toward wellformed sentences. The actors, of course, know better, although certainly not as reflectively as the language scientist: The addition of laughter, fillers, interjections, and hesitation (e.g., repeats and false starts), along with prosodic contributions in the form of intonation, loudness, and rate variations (all of which are not even transcribable without special notational devices), all contribute in a very important supplementary fashion to the final performance level of The third man. In the following research, we will examine how the two types of laughter that do occur specifically serve "as a deliberate, sophisticated, and rhetorical device" (O'Connell \& Kowal 2005: 275) at the 
hands of the English-speaking actors and German-speaking synchronizers in The third man.

The theoretical rationale for comparing the spoken versions (our English and German transcripts) with the written (novel and screenplay) versions of The third man is the concept of orality/literacy. According to Koch and Oesterreicher (1994: 587, our translation), there are two forms of orality/literacy: Medial and conceptual. The former has to do with the modality of discourse and is always dichotomous (phonic vs. graphic), whereas the latter constitutes a continuum:

The term 'conceptual orality/literacy' is accordingly directed toward aspects of linguistic variation which are frequently referred to in research vaguely as 'colloquial language/literary language', 'informal/formal', 'levels of elaborateness' etc.

Koch and Oesterreicher (ibid.: 590) refer to discourse markers, turn-taking signals, speaker and hearer signals, hesitation phenomena, and interjections as contributors to conceptual orality. Other parameters that contribute to the continuum of orality/literacy include communicative setting (e.g., proximity/distance of interlocutors in time and space, privacy/publicity, strong/weak emotionality, and the dialogical/monological [ibid.: $587 \mathrm{f}$;; see also Bader 1994: $46 \mathrm{f}$.]). Reference to self also enhances conceptual orality (see Holly 1996: 34). In our own recent research, we have applied these concepts to the literacy of interviewers, who typically ask their questions from written notes, relative to the orality of interviewees, who typically speak without written notes (e.g., O'Connell \& Kowal 1998; O'Connell \& Kowal 2005; O'Connell, Kowal, \& Dill 2004) and to the relatively literate inaugural rhetoric of American presidents (Kowal, O'Connell, Forbush, Higgins, Clarke, \& D'Anna 1997). O'Connell et al. (2004) also review the recent history of research on orality/literacy. In the present research, we postulate that laughter is a contributor to conceptual orality in the film performance relative to the literacy of the written sources (novel and screenplay) of The third man.

\section{Database}

The database for our empirical analyses of laughter is primarily the complete transcripts of the English- and German-language soundtracks of the actors' parts as prepared by the present authors. Both authors are fluent in both English and German. The first author's native language is English, the second author's German. When the acoustic identity of syllables was in doubt, both authors consulted with one another, and if necessary, the doubtful material was subjected to acoustic analysis by means of the PRAAT software (www.praat.org). If the acoustic identification still remained unclear, that portion was transcribed simply as a parenthesis with the approximate number of syllables noted, e.g., (4 syl).

\section{Response measures}

In order to trace the transformation of laughter notation from the well-formed written text of the novel, through the screenplay, its footnotes, and the www.geocities.com 
English and Timmermann and Baker's (2002) German transcripts to the final spontaneous dialogue in the performance versions of The third man and Der dritte Mann (i.e., the authors' transcripts), a number of response measures that we have found to be characteristic of both conceptual and medial orality (Koch \& Oesterreicher 1994), spontaneous dialogue, and personal perspective (e.g., Alber, O'Connell, \& Kowal 2002; O'Connell \& Kowal 2005; O'Connell et al. 2004; and Suleiman, O'Connell, \& Kowal 2002) must be identified and analyzed. Primary among these, for the purposes of this research, are syllables of laughter and another, somewhat larger unit, instances of laughter, i.e., sequences of laughter syllables uninterrupted by non-laughter.

In their effort to establish the acoustic features of human laughter, Bachorowski, Smoski, and Owren (2001: 1582) began with a rather primitive operationalization of laughter, as we all must: "Any perceptibly audible sound that an ordinary person would characterize as a laugh if heard under ordinary everyday circumstances." There are two basic types of laughter (see O'Connell \& Kowal 2004, 2005): (1) ha-ha laughter and (2) overlaid laughter, i.e., laughter that occurs as an overlay on the syllables of spoken words themselves. The ha-ha type can be realized as a variety of non-word syllables, e.g., HU, HE, HI, HEE, HO, HM, UH; it becomes indiscriminable, incapable of a plausible orthography, and definitionally marginal when realized as any of a variety of grunts, screeches, or animal-like noises. Overlaid laughter is just that: Syllables of lexical items that are prolonged and/or distorted, and thereby carry laughter. O'Connell and Kowal (2005, Example 8) give an example from an interview of Bill Clinton of his pronunciation of the word days as da-hays as part of such laughter.

All instances of both types of laughter were identified, and the duration in seconds (s) of each instance was measured by means of the PRAAT software for acoustical analyses (www.PRAAT.com). These analyses are presented (sequentially through the course of the film) for each speaker in both the English- and Germanlanguage versions of The third man, respectively, in Tables 1 and 2. Therein, and throughout the remainder

\section{Table 1}

Instances (\#, Listed Sequentially) and Durations in Seconds (s) of Laughter by Speakers in the English-Language Version of the Film The third man: Variants of Ha-Ha Laughter in Capitals; Laughter Overlaid on Words Underlined; Instance Number from Table 2 in Parentheses Where Overlap of Instances (IO) Occurs across English and German Versions; Specific Functions (F) of Laughter (Cynical [C], Embarrassed [Em], Humorous [Hu], Hypocritical [Hy], Ironic [I], Mendacious [M], and Pleasant [P])

\begin{tabular}{|c|c|c|c|c|}
\hline \# $\mathrm{IO}$ & Speaker & Laughter & $\mathrm{s}$ & $\mathrm{F}$ \\
\hline 1. & Narrator & HU (unvoiced) wonderful & 0.89 & $\mathrm{I}$ \\
\hline 2. & Porter & $\mathrm{HEH}$ & 0.28 & $\mathrm{I}$ \\
\hline 3. & Kurtz & HU (unvoiced) & 0.15 & $\mathrm{C}$ \\
\hline 4. & Porter & ich kann nit & 0.65 & Em \\
\hline 5. & Porter & UH I' YO & 0.57 & Em \\
\hline
\end{tabular}


6. Kurtz HUHM

$0.25 \quad \mathrm{C}$

7. (3.) Kurtz HU HU you'll do better to think of yourself $\quad 2.29 \quad \mathrm{C}$

8. (4.) Martins HU I'll be all right $\quad 1.83 \quad$ Em

9. (5.) Kurtz of course I'm so glad I met you 3.15 Hy

10. Martins NA HM $\quad 0.27 \quad$ Em

11. Porter HE HO $0.27 \quad$ Em

12. (8.) Crabbin HE HM HO HO UH but of course you do

(9.) good night young man oh I've forgotten my hat I'll let you know the time later $\quad 4.74 \quad \mathrm{Hu}$

13. Kurtz you 0.36 Hy

14. (10.) Popescu but you have to break the rules sometimes $\quad 2.28 \quad \mathrm{C}$

15. (11.) Popescu HM HU I oughtn't to drink it HU it makes (12.) me acid HU HU

16. Popescu HU $3.46 \quad \mathrm{M}$

17. (17.) Schmidt oh yes yes come in $0.87 \quad \mathrm{P}$

$1.09 \quad \mathrm{P}$

19. (20.) Martins oh that was nine years ago

$1.56 \quad$ Em

20. (24.) Crabbin HA HA HA HA AH Mr. Martins what a relief to see you I was beginning to think something had happened to you come along Mr. Martins everything's ready for you

I was frantic $9.83 \quad \mathrm{Hu}$

21. Crabbin come along Mr. M. follow me $2.16 \quad \mathrm{Hu}$

22. (28.) Popescu HUH $0.16 \quad$ C

23. Schmidt or had a mustache I wouldn't have known $\quad 2.19 \quad \mathrm{P}$

24. Martins UH I am leaving Vienna I don't care whether Harry was murdered by Kurtz or Popescu

6.66 I


25. (30.) Schmidt HU (unvoiced)

26. Martins that's the first time I ever saw you laugh

27. (32.) Lime hello old ma-han h-how are you

28. (33.) Lime talk to me of course come on

29 (5.) Lime what can I do old man I'm dead HU aren't I

30. Lime HU HU HU HU I've got quite a lot on my $\underline{\text { mind }}$

31. (40.) Lime HA HA Holly what fools we are ah talking to each other this way as though I'd do anything to you or you to me you're just a little mixed up about things in general
$<0.20$

$2.18 \quad \mathrm{P}$

2.69 Hy

3.08 Hy

$2.13 \quad \mathrm{C}$

$1.96 \quad \mathrm{C}$

32. (41.) Lime it's the same thing they have their five-year plans and so have I

33. Lime hum don't be so gloomy after all it's not that awful

34. Martins I haven't got a sensible name Calloway

1.93 I

Table 2

Instances (\#, Listed Sequentially) and Durations in Seconds (s) of Laughter by Speakers in the German-Language Version of the Film The third man (Der dritte Mann): Variants of Ha-Ha Laughter in Capitals; Laughter Overlaid on Words Underlined; Instance Number from Table 1 in Parentheses Where Overlap of Instances (IO) Occurs across English and German Versions; Specific Functions (F) of Laughter (Cynical [C], Embarrassed [Em], Humorous [Hu], Hypocritical [Hy], Ironic [I], Mendacious [M], and Pleasant $[\mathrm{P}])$

\begin{tabular}{|c|c|c|c|c|}
\hline $\begin{array}{ll}\# \quad \mathrm{IO} \\
\end{array}$ & Speaker & Laughter & $\mathrm{S}$ & $F$ \\
\hline 1. & Kurtz & $\mathrm{H} \ddot{A}$ & 0.17 & $\mathrm{Hy}$ \\
\hline 2. & Kurtz & $\begin{array}{l}\text { UH HU HU HU komische Ideen } \\
\text { hat die manchmal }\end{array}$ & 2.88 & $\mathrm{C}$ \\
\hline 3. $\quad(7$. & Kurtz & UH HU & 0.60 & M \\
\hline
\end{tabular}


4. (8.) Martins UH HM

5. (9.) Kurtz HU HU HU HU wirklich HU Sie sind ein reizender Mensch

6. Schmidt den Zeiten

$0.63 \quad$ Em

7. Martins sein eigener Chauffeur überfährt ihn sein Arzt kommt zufällig vorbei

$3.48 \quad \mathrm{I}$

8. (12.) Crabbin UH HU HU

$0.49 \quad \mathrm{Hu}$

9. (12.) Crabbin UH HU

$0.40 \quad \mathrm{Hu}$

10. (14.) Popescu UH so was soll man eigentlich nicht jedem erzählen aber Sie waren mir auf den ersten Blick sympathisch

11. (15.) Popescu HM MM

$0.88 \quad \mathrm{M}$

12. (15.) Popescu MM HM MM

$0.83 \quad \mathrm{M}$

13. (15.) Popescu MM HU

$0.46 \quad \mathrm{M}$

14. Popescu MM HM

$0.37 \quad \mathrm{M}$

15. Popescu HM das scheint mir auch so

$1.68 \quad \mathrm{C}$

16. Popescu HU

$0.14 \quad \mathrm{M}$

17. (17.) Schmidt EHE natürlich

$1.27 \quad \mathrm{P}$

18. Schmidt UHU ernsthaft

$0.70 \quad P$

19. Schmidt nein nein nein das heisst nicht heuri'gen

$1.48 \quad \mathrm{P}$

20. (19.) Martins HU HU das ist lange her

$1.85 \quad \mathrm{Em}$

21. Martins $\mathrm{NN}$ na ja das ist nicht ganz einfach

$1.70 \quad$ Em

22. Martins HU

$0.93 \quad \mathrm{I}$

23. Schmidt verzeihen Sie

1.27 Em

24. (20.) Crabbin Gott sei Dank

$0.65 \quad P$

25. Crabbin hier sind wir meine Herrschaften Ende gut alles gut

$2.66 \mathrm{Hu}$


26

Crabbin UH HU HU HU

0.76

$\mathrm{Hu}$

27. Crabbin selbstverständlich nur ein kleines Scherz

$1.28 \quad \mathrm{Hu}$

28. (22.) Popescu HM HM HM wie schade HM

$1.19 \quad \mathrm{C}$

29. Martins ach siebzig Pfund pro Stück

$1.39 \quad \mathrm{I}$

30. (25.) Schmidt HU HU HU HU HU UH

$1.52 \quad \mathrm{P}$

31. Martins furchtbar komisch sein

$1.17 \quad \mathrm{O}$

32. (27.) Lime HU Tag alter Junge wie geht's denn

$2.11 \quad$ Hy

33. (28.) Lime HU natürlich komm

$2.07 \quad$ Hy

34. Lime UH HU früher drängten sie sich hier die

Kinder aber jetzt haben sie kein Geld die armen Teufel

$4.30 \quad \mathrm{C}$

35 (29.) Lime $\underline{\text { ich bin tot }}$

$0.50 \quad \mathrm{C}$

36. Lime mm nein nein

$0.76 \quad \mathrm{C}$

37. Lime HU ja

$0.58 \quad$ Em

38. Lime UHU Opfer

$0.78 \quad \mathrm{C}$

39. Lime nur so

$0.44 \quad$ Hy

40. (31.) Lime Zeug als ob ich dir etwas antun könnte UHU

$2.14 \quad \mathrm{C}$

41. (32.) Lime $\quad H U$ ich ich habe meinen

$1.10 \quad \mathrm{C}$

42. Lime UHU

$0.26 \quad$ Hy

43. Lime dir $\mathrm{HU}$

$0.39 \quad$ Hy

44. Lime adieu Holly

$0.61 \quad$ Hy

45. Martins EH HI

$0.44 \quad E m$

46. Martins nein nein

$1.14 \quad \mathrm{M}$

47. Calloway ich habe ein bisschen darin gelesen 
war ganz nett

48. Balloon

Man HI HI HI HI HI
1.71

$\mathrm{P}$

1.54
$\mathrm{P}$

of this article, ha-ha laughter is presented in all-capital lettering, whereas overlaid laughter is presented with the words underlined. It should be noted that \# 25 in Table 1 is listed approximately as $<0.20 \mathrm{~s}$ because the unvoiced laughter is inaudible and therefore not measurable by means of the PRAAT software. Tables 1 and 2 also include information regarding overlap of laughter in identical verbal contexts across the English- and German-language versions of the film as well as a typology of functions served by the laughter: Cynical (C), Embarrassed (Em), Humorous (Hu), Hypocritical (Hy), Ironic (I), Mendacious (M), and Pleasant (P). These categories were derived by the authors through an analysis of the context in which each instance of laughter occurred.

Frequency of ha-ha laughter and overlaid laughter by speakers who laughed is given in terms of syllables of laughter and overall syllables spoken per syllables of laughter in Table 3 in both the English- and German-language versions of the film. In other words, since the number of syllables spoken varies considerably from actor to actor, the frequency of laughter must be normalized as a ratio of all syllables to syllables of laughter. For example, as the first entry in Table 3 shows, Crabbin spoke 9 syllables of ha-ha laughter and 77 syllables of overlaid laughter in the English version of the film; these are normalized in the table in terms of the 703 syllables spoken overall by Crabbin in the English version (see Table 5) as: $703 / 9=78$ and $703 / 77=9$, respectively Also included in Table 3 are the functions of laughter already identified in Tables 1 and 2 by instances of laughter, but now listed by speaker. 
Table 3

Number (\#) of Syllables (syl) and syl/Response Measure for Ha-Ha Laughter (syl/H) and for Laughter Overlaid on Words (syl/O) for All Speakers in the English-Language and German-Language Versions of the Film The third man; Instances of Laughter (IL) by Function (Cynical [C], Embarrassed [Em], Humorous [Hu], Hypocritical [Hy], Ironic $[\mathrm{I}]$, Mendacious $[\mathrm{M}]$, and Pleasant $[\mathrm{P}]$ ) and by Speaker

\begin{tabular}{|c|c|c|c|c|c|c|c|c|c|c|c|c|c|}
\hline \multirow[b]{2}{*}{ Language } & \multirow[b]{2}{*}{ Speaker } & \multicolumn{2}{|r|}{$\mathrm{Ha}-\mathrm{Ha}$} & \multicolumn{2}{|c|}{ Overlaid } & \multirow{2}{*}{$\begin{array}{c}\text { IL } \\
\#\end{array}$} & \multicolumn{7}{|c|}{ Functions } \\
\hline & & \# & syl/H & I & syl/O & & $\mathrm{C}$ & Em & $\mathrm{Hu}$ & Hy & $\mathrm{I}$ & $\mathrm{M}$ & $\mathrm{P}$ \\
\hline \multirow[t]{8}{*}{ English } & Crabbin & 9 & 78 & 77 & 9 & 3 & 0 & 0 & 3 & 0 & 0 & 0 & 0 \\
\hline & Kurtz & 5 & 149 & 18 & 41 & 5 & 3 & 0 & 0 & 2 & 0 & 0 & 0 \\
\hline & Lime & 8 & 108 & 104 & 8 & 7 & 4 & 0 & 0 & 3 & 0 & 0 & 0 \\
\hline & Martins & 4 & 958 & 59 & 67 & 7 & 0 & 3 & 0 & 0 & 2 & 0 & 2 \\
\hline & Narrator & 1 & 335 & 3 & 112 & 1 & 0 & 0 & 0 & 0 & 1 & 0 & 0 \\
\hline & Popescu & 7 & 77 & 20 & 27 & 4 & 2 & 0 & 0 & 1 & 0 & 1 & 0 \\
\hline & Porter & 6 & 140 & 3 & 279 & 4 & 0 & 3 & 0 & 0 & 1 & 0 & 0 \\
\hline & Schmidt & 1 & 1,450 & 15 & 97 & 3 & 0 & 0 & 0 & 0 & 0 & 0 & 3 \\
\hline$\Sigma$ & & 41 & 322 & 299 & 44 & 34 & 9 & 6 & 3 & 6 & 4 & 1 & 5 \\
\hline \multirow[t]{8}{*}{ German } & $\begin{array}{c}\text { Balloon } \\
\text { Man }\end{array}$ & 5 & 4 & 0 & -- & 1 & 0 & 0 & 0 & 0 & 0 & 0 & 1 \\
\hline & Calloway & 0 & -- & 14 & 142 & 1 & 0 & 0 & 0 & 0 & 0 & 0 & 1 \\
\hline & Crabbin & 9 & 78 & 26 & 27 & 6 & 0 & 0 & 5 & 0 & 0 & 0 & 1 \\
\hline & Kurtz & 12 & 67 & 19 & 43 & 4 & 1 & 0 & 0 & 2 & 0 & 1 & 0 \\
\hline & Lime & 14 & 66 & 69 & 13 & 13 & 6 & 1 & 0 & 6 & 0 & 0 & 0 \\
\hline & Martins & 8 & 513 & 45 & 91 & 9 & 0 & 4 & 0 & 0 & 4 & 1 & 0 \\
\hline & Popescu & 18 & 34 & 35 & . 18 & 8 & 2 & 0 & 0 & 1 & 0 & 5 & 0 \\
\hline & Schmidt & 10 & 176 & 21 & 84 & 6 & 0 & 2 & 0 & 0 & 0 & 0 & 4 \\
\hline$\Sigma$ & & 76 & 174 & 229 & 62 & 48 & 9 & 7 & 5 & 9 & 4 & 7 & 7 \\
\hline
\end{tabular}




\section{Results}

Analyses of the Authors' Transcripts. As Tables 1 and 2 make clear, laughter - both haha and overlaid laughter - occurs in this corpus: There are 34 instances in the Englishand 48 in the German-language version. In other words, despite the temporal constraints of synchronization, there are 14 more instances in the German- than in the English-language version. Overall, only 19 instances of laughter occur in identical contexts of the transcripts in both the English- and German-language versions, i.e., $60 \%$ $(29 / 48)$ of the synchronized instances of laughter in German occur in contexts other than those of the English version. Evidently, the German synchronizers do not hold themselves inflexibly bound by the location of these nonverbal components in the English-speaking actors' performance. Instance \# 16 in both the English- and the German-language version is an excellent example of this difference. In both languages, the single syllable of ha-ha laughter is the same: HU on the part of Popescu. And it has the shortest duration of all the instances in both the English (0.12 s) and the German $(0.14 \mathrm{~s})$ versions. Nonetheless, the two instances do not appear in exactly the same verbal contexts at all: The English context is Popescu's complaint about Austrians' bad citizenship; the German context is a transition from his denial of any knowledge of Joseph Harbin to a comment about Anna Schmidt. As Tables 1 and 2 also indicate, in both versions of the film the two types of laughter occur alone or in combination as a single instance of laughter. These combinations yield the longest instances in the corpus: In English, instance \# 20 in Table 1, on the part of Crabbin (9.83 s); in German, instance \# 34 in Table 2 on the part of Lime (4.30 s). The variability from English to German can be noted in the identical context to Crabbin's \# 20 in Table 1 in the English; in the German, instance \# 24 in Table 2 is the identical verbal context, but it is a very different Gott sei Dank, and is only $0.65 \mathrm{~s}$ in duration.

As Table 3 indicates, overall both actors (English) and synchronizers (German) used more syllables of overlaid laughter than syllables of ha-ha laughter: In English 299 $>41$ syl, in German $229>76$ syl, and summed together $528>117$ syl. Table 3 also shows that there are somewhat more syllables of laughter overall in the English- than in the German-language version $([41+299]>[76+229]$ syl $)$. But ha-ha laughter and overlaid laughter are distributed quite differently in English $(41<299$ syl) and German $(76<229$ syl), with less ha-ha laughter and more overlaid laughter in the English- than in the German-language version. The difference between these two sets of relationships,

normalized in terms of syllables per response measure, is significant $\left(\chi^{2}[d f=1]=\right.$ $20.08, p<0.001)$.

With respect to the functions served by the instances of laughter, Table 3 includes overall a symmetrical division (41 and 41) of negative (Cynical [18], Hypocritical [15], and Mendacious [8]) categories and innocuous (Embarrassed [13], Humorous [8], Ironic [8], and Pleasant [12]) categories. In the English version, there are 16/34 (47\%) negative and 18/34 (53\%) innocuous categories; in the German version, there are 25/48 (52\%) negative and 23/48 (48\%) innocuous categories. The functional symmetry is thus seen to be similar in both versions as well as overall. Of the negative functional categories, all 16 instances in English and all 25 instances in German are articulated by the "bad guys," i.e., the criminals identified as the first man (Baron Kurtz), the second man (Mr. Popescu), and the third man (Harry Lime). Of the 
innocuous functional categories, all but one instance (an Embarrassed instance on the part of Harry Lime in German) are articulated by characters other than the first, second, and third men. In other words, the ratios are: 41 to 1 of negative/innocuous categories for the bad guys' laughter as compared with 0 to 41 of negative/innocuous categories for the remaining characters' laughter.

Despite the fact that The third man, with all its grim moral ugliness, clearly fits the category of film noir, there is no evidence of a salience of weeping over laughing in the film. In fact, only one character (Anna Schmidt) weeps at all. Or rather, she tears visibly on three occasions: (1) when she answers Holly Martins' question ("Anything really wrong with your papers?") about the forgery of her papers ("They're forged."); (2) when Holly Martins explicitly declares his love for her ("I wouldn't stand a chance, would I?"); and (3) as she lies sleeplessly just before the international police arrive to take her to headquarters. There is no sobbing that might be construed as some sort of tragic opposite to laughter, only a gentle tearing: The audience cues are visual only, not acoustic.

To return to Table 3, all speakers who used ha-ha $(\mathrm{H})$ or overlaid $(\mathrm{O})$ laughter are included here; most of the minor characters are not included because they do not laugh at all. Overall syllables per syllables of laughter (syl/H and syl/O) indicate normalized frequencies. Crabbin is a special case: As the comic relief of the film, he has a relatively high frequency of laughter (i.e., in English the second lowest syl/H and syl/O ratios, 78 and 9 respectively; in German moderately low syl/H and syl/O ratios, 78 and 27 , respectively). In fact, when both types of laughter are combined, it becomes clear that Crabbin has almost as much laughter as Harry Lime (in English, 16 and 15 syl/[H + O]; in German, 14 and $22 \mathrm{syl} /[\mathrm{H}+\mathrm{O}]$ respectively). Both Major Calloway and Sergeant Paine do not laugh in the English-language version; in the German-language version, Calloway laughs only once and Paine not at all. The Porter too is a special case because he speaks both his native German and his non-native English in the Englishlanguage version of the film: His laughter is all in the English-language version because it reflects his embarrassment with the English language; in the German-language version, the embarrassment is uncalled for and the laughter disappears entirely. The Balloon Man's index $(\mathrm{syl} / \mathrm{H}=4)$ is also - with only 19 syl altogether spoken by him in the German-language version - clearly idiosyncratic. Otherwise, the first (Kurtz), second (Popescu), and third (Lime) men (the bad guys) have the lowest indices of both types of laughter, syl/H and syl/O, i.e., the highest rates of laughter, in both the Englishlanguage (for syl $/ \mathrm{H}, 149,77$, and 108, respectively; for syl/O, 41, 27, and 8 , respectively) and German-language (for syl/H, 67, 34, and 66, respectively; for syl/O, 43,18 , and 13, respectively) versions of the film. The corresponding ratios for the good guys (Martins, Schmidt, and Calloway) are in each instance higher, therefore with less laughter on their part. In other words, there is no overlap between these data for the good guys and the bad guys. Thus, for example, because she has only one syllable of ha-ha laughter in the entire 1,450 syllables of her English speaking, Anna Schmidt's ratio is $1,450 / 1=1,450 \mathrm{syl} / \mathrm{H}$, and Martins is not far behind with only four syllables of ha-ha laughter in English for 3,831/4 = 958 syl/H.

Table 4 presents the frequency and percentage of instances of ha-ha ( $\mathrm{H}$ only) and overlaid ( $\mathrm{O}$ only) types of laughter and sequential combinations thereof in the English- and German-language versions of the film The third man. Also presented there are the means and standard deviations of the duration of these types of instances in seconds. As Table 4 shows, the simple types of laughter ( $\mathrm{H}$ only and $\mathrm{O}$ only) are the 
most common. When they do combine sequentially, the laughter more commonly (29\%) begins with the ha-ha type and shifts to the overlaid type (H-O, H-O-H, and H-O$\mathrm{H}-\mathrm{O})$, but seldom (4\%) begins with the overlaid type and shifts to ha-ha type of laughter $(\mathrm{O}-\mathrm{H}, \mathrm{O}-\mathrm{H}-\mathrm{O})$. Instances of ha-ha laughter ( $\mathrm{H}$ only) are considerably longer in duration in German than in English $(0.63>0.25 \mathrm{~s})$, whereas instances of all the other categories are longer in duration in English than in German: O only $(2.59>1.28 \mathrm{~s})$; H-O, H-O-H, $\mathrm{H}-\mathrm{O}-\mathrm{H}-\mathrm{O}(3.96>1.98 \mathrm{~s})$; and $\mathrm{O}-\mathrm{H}, \mathrm{O}-\mathrm{H}-\mathrm{O}(2.13>1.26 \mathrm{~s})$. Hence, the duration of instances is longer in English than the duration of instances in German $(2.32>1.28 \mathrm{~s})$. One should note, however, the large standard deviations for all sequencings except $\mathrm{H}$ only.

Table 4

Complexity of Sequencing of Ha-Ha (H) and Overlaid (O) Types of Laughter in the English- and German-Language Versions of the Film The third man: Frequency (\#) and Percentage (\%), and Corresponding Mean $(M)$, and Standard Deviation $(S D)$ of Durations of Instances in Seconds

\begin{tabular}{|c|c|c|c|c|c|c|c|c|c|c|c|c|}
\hline \multirow[b]{2}{*}{ Sequencing } & \multicolumn{4}{|c|}{ English-Language } & \multicolumn{4}{|c|}{ German-Language } & \multicolumn{4}{|c|}{ Overall } \\
\hline & \# & $\%$ & $M$ & $S D$ & \# & $\%$ & $M$ & $S D$ & \# & $\%$ & $M$ & $S D$ \\
\hline H only & 9 & 26 & 0.25 & 0.13 & 16 & 33 & 0.63 & 0.42 & 25 & 30 & 0.50 & 0.39 \\
\hline O only & 15 & 44 & 2.59 & 1.71 & 15 & 31 & 1.28 & 0.84 & 30 & 37 & 1.93 & 1.48 \\
\hline $\begin{array}{l}\mathrm{H}-\mathrm{O}, \mathrm{H}-\mathrm{O}-\mathrm{H} \\
\mathrm{H}-\mathrm{O}-\mathrm{H}-\mathrm{O}\end{array}$ & 9 & 26 & 3.96 & 3.45 & 15 & 31 & 1.98 & 1.19 & 24 & 29 & 2.72 & 2.45 \\
\hline $\mathrm{O}-\mathrm{H}, \mathrm{O}-\mathrm{H}-\mathrm{O}$ & 1 & 3 & 2.13 & -- & 2 & 4 & 1.26 & 1.24 & 3 & 4 & 1.55 & 1.01 \\
\hline$\Sigma$ & 34 & 99 & 2.32 & 2.46 & 48 & 99 & 1.28 & 1.01 & 82 & 100 & 1.71 & 1.83 \\
\hline
\end{tabular}

In Table 5, number and percentage of syllables spoken as well as number of syllables spoken/number of syllables of laughter $(\# / L)$ are presented for the various speakers both in the English- and German-language versions. Data for the first man 
Table 5

Number (\#), Percentage (\%) of Syllables, and Total Number of Syllables/Number of Syllables of Laughter (\#/L) Alphabetically Ordered According to Speaker in the English- and the German-Language Versions of The third man; Data for the First (Kurtz), Second (Popescu), and Third (Lime) Men in Bold Font; Data for Calloway, Martins, and Schmidt in Italic Font

\begin{tabular}{|c|c|c|c|c|c|c|}
\hline \multirow[b]{2}{*}{ Speaker } & \multicolumn{3}{|c|}{ English-Language } & \multicolumn{3}{|c|}{ German-Language } \\
\hline & $\#$ & $\%$ & $\# / \mathrm{L}$ & $\#$ & $\%$ & $\# / \mathrm{L}$ \\
\hline \multicolumn{7}{|l|}{ Balloon } \\
\hline Man & 10 & $<1$ & -- & 19 & $<1$ & 3.8 \\
\hline Barman & 7 & $<1$ & -- & 8 & $<1$ & -- \\
\hline Boy & 56 & $<1$ & -- & 78 & $<1$ & -- \\
\hline Brodsky & 141 & 1 & -- & 173 & 1 & -- \\
\hline Calloway & 1,827 & 14 & -- & 1,986 & 14 & 141.8 \\
\hline \multicolumn{7}{|c|}{ Cemetery } \\
\hline Official & 16 & $<1$ & -- & 17 & $<1$ & -- \\
\hline Crabbin & 703 & 5 & 8.2 & 698 & 5 & 19.9 \\
\hline Doorman & 3 & $<1$ & -- & 42 & $<1$ & -- \\
\hline \multicolumn{7}{|l|}{ Girl at } \\
\hline Wheel & 6 & $<1$ & -- & 4 & $<1$ & -- \\
\hline Kurtz & 744 & 6 & 33.8 & 808 & 6 & 26.1 \\
\hline Landlady & 556 & 4 & -- & 518 & 4 & -- \\
\hline Lime & 865 & 7 & 7.7 & 918 & 6 & 11.2 \\
\hline Maid & 16 & $<1$ & -- & 0 & -- & -- \\
\hline Martins & 3,831 & 29 & 60.8 & 4,101 & 29 & 77.4 \\
\hline Narrator & 335 & 3 & 83.8 & 389 & 3 & -- \\
\hline Paine & 393 & 3 & -- & 434 & 3 & -- \\
\hline Police & 133 & 1 & -- & 119 & $<1$ & -- \\
\hline Popescu & 538 & 4 & 20.3 & 619 & 4 & 11.7 \\
\hline Porter & 838 & 6 & 93.1 & 742 & 5 & -- \\
\hline Priest & 216 & 2 & -- & 188 & 1 & -- \\
\hline Schmidt & 1,450 & 11 & 90.5 & 1,760 & 12 & 56.8 \\
\hline Taxi Driver & 36 & $<1$ & -- & 36 & $<1$ & -- \\
\hline \multicolumn{7}{|l|}{ Theater } \\
\hline People & 19 & $<1$ & -- & 18 & $<1$ & -- \\
\hline Trainman & 3 & $<1$ & -- & 3 & $<1$ & -- \\
\hline Waiter & 7 & $<1$ & -- & 12 & $<1$ & -- \\
\hline Wife of Por & rter 17 & $<1$ & -- & 17 & $<1$ & -- \\
\hline Winkel & 227 & 2 & -- & 230 & 2 & -- \\
\hline (Wo)men & 214 & 2 & -- & 258 & 2 & -- \\
\hline
\end{tabular}


Totals $\quad 13,205$

100

(Kurtz), the second man (Popescu), and the third man (Lime) - the bad guys - are printed in bold font, and data for Calloway, Martins, and Schmidt - the good guys - in italic font to indicate that most of the speaking and laughing are done by only a very few characters. In general, the percentage of spoken syllables that are also laughter syllables is quite low in both the English- $(340 / 13,205=2.6 \%)$ and the Germanlanguage $(305 / 14,195=2.1 \%)$ versions. The fact that the percentages of syllables spoken by individuals are almost identical across the English- and German-language versions reflects the process of synchronization.

In both languages, Martins accounts for $29 \%$ of the speaking; he is present in every extended scene of the entire movie. But it is Lime who has the lowest normalized index of syllables per laughter (and hence the highest proportion of laughter), both in English ( $\# / \mathrm{L}=7.7 \mathrm{syl})$ and in German (\#/L=11.2 syl), and among the major characters, Popescu and Kurtz, both with indices well below the overall indices of \#/L for both English and German, are close behind Lime. In other words, apart from the comic relief of Crabbins, the first, second, and third men laugh proportionately more than the other major characters. Paradoxically, Lime, the third man, has only a very short period of visibility in the entire film $(<12 \mathrm{~min})$ in which to establish convincingly his evil character. His dominant use of Cynical, Hypocritical, and Mendacious categories of laughter is an important means to this end on the part of Orson Welles. By way of contrast, Calloway does not laugh at all in English and has the highest index of syllables per laugh in German ( $\# / \mathrm{L}=141.8 \mathrm{syl}$ ) of any of the speakers who laugh. Through his laughter, Lime proclaims himself as villain; without laughter, Calloway appears as the sober voice of reason and right order.

The variations in amount of laughter from English to German can also be considered in terms of overall time of laughter per speaker. Lime, Crabbin, and Martins all spent more time (respectively: $28.43>16.04,16.73>6.24$, and $15.52>11.28 \mathrm{~s}$ ), but fewer instances (respectively: $7<13,3<6$, and $7<9$ ) of laughter in the Englishlanguage than in the German-language version, whereas Popescu, Kurtz, and Schmidt all spent less time laughing in the English-language version (respectively: $6.02<9.80$, $6.20<6.85$, and $3.26<6.87 \mathrm{~s}$ ). Lime alone accounts for most of the difference in time overall from English to German $(12.39 / 18.49 \mathrm{~s}=67 \%)$. Together, the first man (Kurtz), the second man (Popescu), and the third man (Lime), the bad guys, account for more than half $(40.65 / 78.82 \mathrm{~s}=52 \%)$ of the laughter time in the English-language version; Harry Lime alone accounts for $36 \%$. In the German-language version, these three account for only $32 \%$ of the laughter time; Harry Lime in turn for only $26 \%$, largely because of his shift in German to the ha-ha laughter and away from overlaid laughter and because of his faster speech rate in the German-language version (see Table 6 below). All these differences reflect the flexibility of the synchronization process.

In Table 6, duration in seconds and syllables of the four longest dialogical turns of four major characters in the film - Lime, Calloway, Martins, and Schmidt - are shown. In all instances, the passage in German has a number of syllables equal to or greater than 
Table 6

The Turns of Longest Duration in Seconds (s) and Syllables (syl) and Speech Rate in syl/s for Each of the Four Speakers Who Spoke the Most Syllables in the English- and German-Language Versions of The third man

\begin{tabular}{llccccc}
\hline Speaker & \multicolumn{2}{l}{ English-Language Version } & & & German-Language & Version \\
& $\mathrm{s}$ & $\mathrm{syl}$ & $\mathrm{syl} / \mathrm{s}$ & $\mathrm{s}$ & $\mathrm{syl}$ & $\mathrm{syl} / \mathrm{s}$ \\
\hline Lime & 68.79 & 257 & 3.74 & 66.03 & 283 & 4.29 \\
Calloway & 19.46 & 92 & 4.73 & 18.69 & 92 & 4.92 \\
Martins & 19.14 & 45 & 2.35 & 18.63 & 58 & 3.11 \\
Schmidt & 18.89 & 48 & 2.54 & 18.37 & 48 & 2.61 \\
Totals & 126.28 & 442 & 3.50 & 121.72 & 481 & 3.95 \\
\hline
\end{tabular}

the same passage in English, but a shorter duration than in English. This finding provides evidence for our hypothesis that the speech rates (syl/s) are faster in the German-language version than in the English-language version of the film. And this in turn provides an explanation of how more syllables can be used in the German to synchronize with a smaller number of syllables in the English $(14,195>13,205$ syl) within the same time frame.

Comparisons Involving the Novel, the Screenplay, and Transcripts Other than the Authors'. In the novel itself, there are more tears than in the film, and in the film, there is more laughter than in the novel. We have noted above that there is no sobbing in the film that could be construed as syllabically parallel to ha-ha laughter, and the three occasions when Anna Schmidt is seen tearing do not overlap at all contextually with the weeping reported in the novel: (1) Martins weeps at the first funeral of Harry Lime: "The tears of a boy ran down his thirty-five-year-old cheeks" (Greene 1950: 15; see also ibid.: 24); (2) Anna Schmidt weeps as well: "A girl stood a little way away with her hands over her face" (ibid.: 24), and [Martins to Harry Lime] "she was there too - in tears" (ibid.: 135). In stark contrast, we find the following with regard to the second funeral:

When Harry Lime had his second funeral. . . . The group by the grave was smaller now: Kurtz wasn't there, nor Winkler - only the girl [Anna Schmidt] and Rollo [Holly] Martins and myself [Major Calloway]. And there weren't any tears. (ibid.: 156)

As for laughter, there is very little of it in the novel. However, something less than laughter is frequently indicated: (1) A celebrity flashes "a false headline smile" (ibid.: 18); (2) there is "an air of grotesque comedy" (ibid.: 22) at the cemetery; (3) 
Martins gives "a grin which took five years off his age" (ibid.: 29); (4) "Martins brought out a surface smile" (ibid.: 31); (5) there is "a stranger who grinned at him [Martins]" (ibid.: 41) in a dream; (6) Kurtz gives "one of his studied Viennese smiles, . . . and brushed out the smile as though it had never been" (ibid.: 49); (7) Anna Schmidt reports "a lot of comedy involved in these situations if you're not directly concerned" (ibid.: 121); (8) Kurtz "smiled at him [Martins] like a conspirator" (ibid.: 132); (9) Harry "came with his amused deprecating take-it-or-leave-it manner" (ibid.: 132); (10) "Harry smiled back at Rollo Martins" (ibid.: 136); and (11) Harry "gave his boyish conspiratorial smile" (ibid.: 137).

By contrast, minor characters actually laugh: (1) "the curious free uniformed laughter" of a group of "G.I.'s with their girls" (ibid.: 73); (2) "the man [father of the little boy who accuses Martins of murdering the porter] gave a big laugh" (ibid.: 86); and (3) a police officer (Bates in the novel, Paine in the film) who is slightly wounded (mortally in the film) laughs ironically: "He gave a low laugh" (ibid.: 151). But there are only two occasions in the novel wherein principal characters laugh: (1) "He [Martins] laughed" (ibid.: 28) after imbibing a number of drinks provided by Calloway; and (2) Anna Schmidt laughs at Martins:

"You make me cross."

Suddenly she laughed. She said, "You are so comic. You came here at three in the morning - a stranger - and say you love me. Then you get angry and pick a quarrel. What do you expect me to do - or say?"

"I haven't seen you laugh before. Do it again. I like it."

"There isn't enough for two laughs," she said. (ibid.: 116)

Only this second instance from the novel is paralleled by laughter in the film: In the English-language version, with a single unvoiced syllable of ha-ha laughter (see Table 1, \# 25), and in the German-language version, with six syllables of ha-ha laughter (see Table 2, \# 30.). But there is no trace of any of the negative (Cynical, Hypocritical, and Mendacious) typologies of laughter anywhere in the novel itself; these are saliently characteristic of the film only and are articulated only by the first (Kurtz), second (Popescu), and third (Lime) men, the bad guys.

The screenplay (Greene 1984) provides yet another, intermediate version of weeping and laughter. Anna Schmidt "begins to cry quietly" (ibid.: 65) while speaking of Lime to Martins. In addition to the two instances of laughter on the part of principal characters in the novel (Martins [ibid.: 25] and Schmidt [ibid.: 84]), Kurtz "sniggers" (ibid.: 32). Also, in the context of a "laughing, cheery photograph of HARRY," Martins says:

We laughed at the same things. He couldn't bear the colour green. But it wasn't true. He never existed, we dreamed him. Was he laughing at fools like us all the time?

Anna sadly: He liked to laugh. (ibid.: 83)

Also, audience laughter at the Josefstadt Theatre is recorded (ibid.: 38); "The FRENCH M.P. laughs" (ibid.: 90), and "FRAU KURTZ goes off into a peal of laughter" (ibid.: 93) upon hearing her husband referred to as "The Baron." But, as in the novel, there is 
no laughter on the part of Harry Lime; it is reduced to smiling (ibid.: 97) and grinning (ibid.: 113).

Perhaps most surprising is the version of laughter available from www.geocities.com. Apart from several texts about laughter (e.g., Anna Schmidt's "Sometimes he [Lime] said I laughed too much" [ibid.: 12] and the exchange:

MARTINS: I knew him for twenty years, at least I thought I knew him. I suppose he was laughing at fools like us all the time.

ANNA: He liked to laugh. [ibid.: 22]

and Martins' comment to Schmidt: "First time I saw you laugh" [ibid.: 23]), there is no indication or notation of laughter in this entire transcript.

\section{Discussion}

The dynamic of our analyses of laughter in The third man has proceeded from literacy to orality. It goes without saying that this process is from the written to the spoken, from graphic to phonic - from medial literacy to medial orality. But it is also a matter of conceptual literacy and conceptual orality (Koch \& Oesterreicher 1994), and "to date there has been very little empirical research regarding markers of conceptual orality/literacy in dialogue" (O'Connell et al. 2004: 188).

In the English-language version of the film, this dynamic proceeds as follows: Novel $\rightarrow$ screenplay + footnotes $\rightarrow$ www.geocities.com transcript $\rightarrow$ authors' transcript $\rightarrow$ film. In the German-language version, Der dritte Mann, it proceeds as follows: Novel $\rightarrow$ Timmermann and Baker (2002) transcript $\rightarrow$ authors' transcript $\rightarrow$ film. Historically, this dynamic is just the reverse of the considerations we engaged with regard to Hannah Arendt's famous 1964 interview with Günter Gaus (O'Connell \& Kowal 1998). There the dynamic was from orality to literacy as follows: Interview $\rightarrow$ authors' transcript $\rightarrow$ interview published by the interviewer himself (e.g., Gaus 1965).

The passage of spontaneous discourse from orality to literacy involves the inevitable deletion of most of the following: Hesitations (including filled pauses, false starts, and repeats); overlaps and interruptions in turn-taking; silent pauses; paralinguistic phenomena (e.g., laughter, throat clearing, coughing, and audible sighing); contractions, elisions, and dialectal pronunciations; back channel signals; tag questions; interjections and discourse markers; and, of course, the prosodic elements of intonation, loudness, and articulation rate, and their variation. In exchange, one acquires grammatical well-formedness, along with

devices such as paragraphing, capitalization, punctuation, and the elimination of redundant, unclear, unsyntactic, dialectal, incomplete, and hesitant elements. Further, a level of formal correctness is added, and many personalized, very human nuances disappear in favor of an objectivized level of discourse. At an even more basic level, legibility is made possible. (O'Connell \& Kowal 1998: 554)

In the present research, we began with Graham Greene's $(1950,1962)$ novel and traced the changes in weeping and laughter: 
(1) In keeping with the grim story, both Martins and Schmidt wept at Lime's first funeral, but only in the novel. There is no trace of such weeping in the film, only three other contexts in which Schmidt is shown tearing, but not sobbing in anything like an analogue to syllables of laughter.

(2) Changes in laughter occur as well. In the novel, only two instances of laughter on the part of major characters are described. Only one of these - Anna Schmidt's laughter at Holly Martins - survives in the film, but not his drunken laughter when drinking with Calloway. However, in the film, numerous additional instances of laughter occur elsewhere. Most of this additional laughter in the film is laughter on the part of the bad guys: The first, the second, and, in particular, the third man. Hence the paradox: The third man, Harry Lime, speaks in the dialogue less than six minutes of the total duration of the movie $(5.96 / 102.25 \mathrm{~min}=5.8 \%)$, and yet he accounts for a disproportionate amount of the laughter time in both the English-language $(36 \%)$ and the Germanlanguage $(26 \%)$ versions of the film. This finding is quite in accord with the screenplay's (Greene 1984: 83) characterization of Harry Lime in Anna Schmidt's words: "He liked to laugh."

The overall pattern of laughter in all these versions of The third man is important for a general theory of laughter. First of all, in the film, the laughter is not stereotyped as Provine (1996) would have predicted. Instead, it occurs with a marvelous array of sounds, even within a short span of syllables, as in Crabbin's "HE HM HO HO UH but of course. .." (Table 1, \# 12), which becomes "UH HU HU" (Table 2, \# 8) in the German version.

Provine (2004: 215) also reported that laughter typically follows upon nonhumorous and banal comments. Our findings in the present corpus of laughter would be largely in accord with his first characterization, but as O'Connell and Kowal (2004) have observed, the methodology used by Provine (1993: 293) precluded a valid examination of preceding context. In the present corpus, the immediately preceding context was found to be purposefully related to the laughter and not banal at all. In fact, laughter typically involved an immediately antecedent context that was neither humorous nor banal. What this really indicates is that the connection of laughter to humor is exceedingly tenuous. And this in turn leads to something even more important: According to Chafe (2003a: 41), laughter is necessarily associated with "the feeling of nonseriousness," a feeling that is essentially "pleasant." But O'Connell and Kowal (2004; see also Harris 1999: 345; and Keltner \& Bonanno 1997: 687) found that laughter could be associated with earnestness and even grim settings.

These generalizations are important background for the use of laughter in The third man, where 50\% (41/82 instances across both English and German versions of the film) of the laughter on the part of the first, second, and third men (the bad guys) occurs in settings that are Cynical, Hypocritical, or Mendacious, and much (12 instances) of the laughter on the part of other characters is in contexts in which they are Embarrassed. Almost two thirds of the unexpectedly high incidence of laughter in this film noir is accounted for by these categories. In other words, the laughter that typically occurs in The third man does not fit Provine's (2004: 215) definition of laughter as "an instinctive, contagious stereotyped, unconsciously controlled, social play vocalization that is unusual in solitary settings." Nor is it typically "spontaneous and relatively uncensored" (ibid.: 216). Provine does acknowledge what he calls "laugh-speak, a curious hybrid in which you speak in a laughing manner" that is "more nuanced, is under more conscious control, and probably involves different brain mechanisms than 
the discrete 'ha-ha' laugh" (ibid.: 216). Our data indicate rather that the laughter overlaid on words (Provine's "laugh-speak") is not a "curious hybrid," but the dominant form of laughter in this corpus (in English, 299 > 41 syl; in German, $229>76$ syl; and overall $528>117$ syl; see Table 3) - a form with which ha-ha laughter is linked in 28/82 or one third (34\%) of all the instances of laughter that occurred (see Table 4). In other words, the two forms of laughter flow into one another and are far more closely allied than Provine acknowledges.

Far more important is the fact that both forms reflect in every instance the personal perspectives of the laughter and are used by the laugher as deliberate, sophisticated, and rhetorical devices (see O'Connell \& Kowal 2004, 2005). One could well argue that the necessarily expeditious presentation of Harry Lime's character as an evil man in less than six minutes of speaking with Holly Martins in The third man both exemplifies dramatically a communication of personal perspectives and a use of laughter not only in a very skillful, dramatic, rhetorical episode, but in the key episode in which the central rationale of the film narrative becomes crystal clear: Harry Lime is not the victim of a senseless murder plot; he is the vicious criminal behind the entire "ugly story" (Greene 1950: 16). Again, to be noted is the fact that none of his seven instances of laughter in the English-language version and none of his 13 instances of laughter in the German-language version is indicated or notated in any way in the novel, in the screenplay, in the www.geocities.com transcript, or in the Timmermann and Baker (2002) transcript. In the terminology used by Goffman (1981: 226), Harry Lime, and indeed all the actors and synchronizers participate in authorship of the film as "principal" rather than simply as "animator," by means of their laughter.

An enactment of life comes to life on screen or stage as medial and conceptual orality, with all the prosodic, paralinguistic, and verbal devices necessary to lure an audience into the dramatic convention. As recently as the 2005 Cannes Film Festival (Baker 2005), the historical judgment of greatness has once again been delivered. Harry Lime's self-presentation at the Ferris wheel is an essential key in this greatness; and central to his presentation is his magnificent, deliberate, dramatic, rhetorical use of both forms of laughter in close conjunction with one another. Amazingly, since, as the film audience well knows, Harry Lime is putatively already dead:

\section{Harry Lime: what can I do old man I'm dead HU aren't I}

We have deliberately omitted punctuation from within the citation, since punctuation is itself a vestige of the literate. The sense of the passage can only be reconstructed as an instance of both medial and conceptual orality, implemented by both ha-ha laughter and laughter as an overlay on words. Will the real Harry Lime please stand up? Yes, given the devices available for the purpose, he can stand before us, the audience, with his subtle, cynical, hypocritical, mendacious laughter.

\section{References}

Alber, J., D.C. O'Connell, and S. Kowal (2002) Personal perspective in TV interviews. Pragmatics 12: 257-271. 
Bachorowski, J.-A., M.J. Smoski, and M.J. Owren (2001) The acoustic features of human laughter. Journal of the Acoustical Society of America. 110: 1581-1597.

Bader, E. (1994) Rede-Rhetorik, Schreib-Rhetorik, Konversations-Rhetorik: Eine historisch-systematische Analyse. Tübingen: Gunter Narr.

Baker, F. (2005) Shadowing the third man [Motion picture]. (Available from SILVERAPPLES MEDIA LTD. - Avril MacRory - 19, Geraldine Road, London SW18 2NR UK)

Chafe, W. (2003a) Laughing while talking. In D. Tannen \& J.E. Alatis (eds.), Georgetown University round table on languages and linguistics 2001. Linguistics, language, and the real world: Discourse and beyond. Washington, DC: Georgetown University Press, pp. 36-49.

Chafe, W. (2003b) Importance of not being earnest. Paper presented at the meeting of the International Society for Humor Studies, Chicago, IL.

Gaus, G. (1965) Gespräch mit Hannah Arendt. München: Piper.

Glenn, P. (2003) Laughter in interaction. Cambridge: Cambridge University Press.

Goffman, I. (1981) Forms of talk. Philadelphia: University of Pennsylvania Press.

Greene, G. (1950) The third man [Novel]. Harmondsworth, Middlesex, England: Penguin Press.

Greene, G. (1962) Der dritte Mann [Roman]. Wien: Paul Zsolnay Verlag.

Greene, G. (1984) The third man (rev. ed.) [Screenplay]. London: Lorrimer.

Harris, C.R. (1999) The mystery of ticklish laughter. American Scientist 87: 344-351.

Holly, W. (1996) Mündlichkeit im Fernsehen. In B.U. Biere \& R. Hoberg (eds.), Mündlichkeit und Schriftlichkeit im Fernsehen. Tübingen: Gunter Narr. pp. 29-40.

Keltner, D., and G.A. Bonanno (1997) A study of laughter and dissociation: Distinct correlates of laughter and smiling during bereavement. Journal of Personality and Social Psychology 73: 687-702.

Joubert, L. (1579/1980) Treatise on laughter (D. de Rocher, Trans.). University, AL: University of Alabama Press. (Original published 1579)

Koch, P., \& W. Oesterreicher (1994) Schriftlichkeit und Sprache. In H. Günther \& O. Ludwig (eds.), Schrift und Schriftlichkeit. Writing and its use. Ein interdisziplinäres Handbuch internationaler Forschung. An interdisciplinary handbook of international research (Vol. 1). Berlin: de Gruyter, pp. 587-604.

Korda, A., D.O. Selznik (Producers), \& C. Reed (Director) (1949) The third man [Motion picture]. (Available from Home Vision Cinema, 4411 N. Ravenswood Avenue, Chicago, IL 60640-5802)

Korda, A., D.O. Selznik (Producers), \& C. Reed (Director) (1962) Der dritte Mann [German Synchronization]. (Available from Atlas Film)

Kowal, S., D.C. O’Connell, K. Forbush, M. Higgins, L. Clarke, and K.D'Anna (1997) Interplay of literacy and orality in inaugural rhetoric. Journal of Psycholinguistic Research 26: 1-31.

Linell, P. (1998) Approaching dialogue: Talk, interaction and context in dialogical perspectives. Amsterdam: John Benjamins Publishing Company.

Linell, P. (1982/2005) The written language bias in linguistics. London: Routledge. (Originally published in 1982) 
Merriam-Webster's collegiate dictionary (11 $1^{\text {th }}$ ed.) (2003) Springfield, MA: Merriam-Webster.

O’Connell, D.C., and S. Kowal (1998) Orality and literacy in public discourse: An interview of Hannah Arendt. Journal of Pragmatics 30: 543-564.

O'Connell, D.C., and S. Kowal (2004) Hillary Clinton's laughter in media interviews. Pragmatics 14: 463-478.

O’Connell, D.C., and S. Kowal (2005) Laughter in Bill Clinton's My life (2004) interviews. Pragmatics 15: 275-299.

O’Connell, D.C., S. Kowal, and E.J. Dill III (2004) Dialogicality in TV news interviews. Journal of Pragmatics 36: 185-205.

Plessner, H. (1961) Lachen und Weinen: Eine Untersuchung nach den Grenzen menschlichen Verhaltens $\left(3^{\text {rd }}\right.$ ed.). Bern: Francke Verlag.

Provine, R.R. (1993) Laughter punctuates speech: Linguistic, social and gender contexts of laughter. Ethology 95: 291-298.

Provine, R.R. (1996) Laughter. American Scientist 84: 38-45.

Provine, R.R. (2000) Laughter: A scientific investigation. New York: Penguin.

Provine, R.R. (2004) Laughing, tickling, and the evolution of speech and self. Current Directions in Psychological Science 13: 215-218.

Sinclair, A. (1984) Introduction. In A. Sinclair (ed.), The third man (rev. ed.) [Screenplay]. London: Lorrimer.

Suleiman, C., D.C. O'Connell, and S. Kowal (2002) "If you and I, if we, in this later day, lose that sacred fire. ..": Perspective in political interviews. Journal of Psycholinguistic Research 31: 281-299.

Timmermann, B., and F. Baker (2002) Der dritte Mann: Auf den Spuren eines Filmklassikers. Wien: Czernin Verlag.

Washburn, R.W. (1929) A study of smiling and laughing of infants in the first year of life. Genetic Psychology Monographs 6: 397-535. 